\begin{tabular}{c} 
International Journal of Applied Mathematical Research, $7(1)(2018) 7-9$ \\
International Journal of Applied Mathematical Research \\
Sebsite: $\begin{array}{c}\text { www.sciencepubco.com/index.php/IJAMR } \\
\text { doi: } 10.14419 / \text { ijamr.vil.7315 } \\
\text { Research paper }\end{array}$ \\
\hline
\end{tabular}

\title{
The effects of water level shrinkage in the Lake Chad Basin on costs of production of local residents
}

\author{
Abba Danna ${ }^{1}$, Bakari Abbo ${ }^{2}$ and Youssouf Pare ${ }^{3 *}$ \\ ${ }^{1}$ Université de N'Djamena; Faculté des Sciences Exactes et Appliqués département de Mathématiques et d'Informatique \\ ${ }^{2}$ Université de N'Djamena; Faculté des Sciences Exactes et Appliqués département de Mathématiques et d'Informatique \\ ${ }^{3}$ Uniersité Ouaga I Pr Joseph Ki Zerbo ;Unité de formation et de Recherche en Sciences exactes et Appliqués \\ *Corresponding author E-mail: pareyoussouf@yahoo.fr
}

\begin{abstract}
In this paper, we are interested at the modeling and nummerical simulation of the impact of dewatering of Lake Chad on income riverains, to help decision-makers to take the approprite meqsures. But in these case, we use the dual of simplex method in order to minimizing the three "targets" population production costs.
\end{abstract}

Keywords: Operation research, mathematical programming; population; revenues, dual problem of simplex method, minimizing

\section{Introduction}

In a previous article, we looked at the effects of the drying up of Lake Chad Basin on the economic income of the surrounding three categories of residents (fishermen, farmers and breeders). However, we focused much more on the evolution of economic income of the target population, by treating the primal problem. In this approach, we paid special attention to the idea of profit maximization -if there are any- and in doing so, we demonstrated a considerable decline in revenues of local residents. But this time, we propose to consider the dual problem in order to verify the possibilities of improving the income of local residents by minimizing production costs of the three "target" populations under consideration. Of course, this approach is well represented in the current literature.

\section{Background and Rationale}

Located in the heart of the Sahel, Lake Chad, is a vital water resource for fishermen, breeders and farmers of the four riparian countries: Niger, Nigeria, Chad, and Cameroon. The lake has undergone significant changes in recent decades. Fifty years ago, it was comparable to an inland sea with an area of $20000 \mathrm{~km} 2$. Repeated hard-felt droughts in the 1970s and 1980s, have led to its rapid drying, and its area shrank to about $2.000 \mathrm{~km} 2$. This gradual drying of the lake has become emblematic of the ongoing climate change and results in its wake,in disastrous consequences on the environment and people.

The "Transaqua" project which aims to replenish the lake has been advocated over thirty years and shown as the best option by the Lake Chad Basin Commission (LCBC). The project should enable a transfer of water from the Ubangi Riverwhich originates in the Democratic Republic of The Congo (DRC), to the lakevia the Chari and Logone rivers. This solution is far from unanimous as many are skeptical over it. Environmentalists believe that the project would have a negative impact on the biodiversity of the Ubangi Riverand the Congo Basin, and that for this type of project, the negative effects often outweigh the benefits.

A second solution is studying the feasibility of drilling the underground waters beneath the lake. Other options are also proposed for solving the lake's shrinking phenomenon. Most of the proposed solutions have shown their limits and advantages. It is in this light, and to show the extent of this phenomenon on the economic plan that we propose to carry out this research that aims to show the evolution of the income of local residents (fishermen, farmers and breeders) to enable policy makers to take adequate measures and help this exposed population.

Thus, we have limited our work on economic modeling and the digital simulation of the phenomenon of lake water drying up through this work under the theme of "Problems of dewatering and their impact on the economic costs of production for local populations".

\subsection{Objectives}

\subsubsection{General Purpose}

The project aims to bring a contribution to the preservation of Lake Chad and its socio-economic and environmental role for the neighboring countries, while respecting the preservation of ecosystems and concerted and rational management of water resources. 
Table 1: Results of the four quarters of production operations 1960-1975.

\begin{tabular}{|l|l|l|l|l|}
\hline $\begin{array}{l}\text { Duration in } \\
\text { hour per tons } \\
\text { of the products }\end{array}$ & $\begin{array}{l}\text { Number } \\
\text { of hours } \\
\text { per ton } \\
\text { of fish } \\
\begin{array}{l}\text { Quarteriy } \\
\text { Subdivisions }\end{array}\end{array}$ & $\begin{array}{l}\text { Number } \\
\text { of hours } \\
\text { per ton } \\
\text { of } \\
\text { agricultural } \\
\text { Products }\end{array}$ & $\begin{array}{l}\text { Number } \\
\text { of hours } \\
\text { per ton of } \\
\text { Breeding } \\
\text { Products }\end{array}$ & $\begin{array}{l}\text { Available } \\
\text { Hour } \\
\text { Volumes }\end{array}$ \\
\hline $\begin{array}{l}1^{\text {er }} \text { Quarter } \\
\text { (January-March) }\end{array}$ & 20 hours & 40 hours & 60 hours & $\begin{array}{l}3870 \\
\text { hours }\end{array}$ \\
\hline $\begin{array}{l}2^{\text {nd }} \text { Quarter } \\
\text { (April-June) }\end{array}$ & 40 hours & 60 hours & 80 hours & $\begin{array}{l}6160 \\
\text { hours }\end{array}$ \\
\hline $\begin{array}{l}3^{\text {rd }} \text { Qarter } \\
\text { (July- } \\
\text { September) }\end{array}$ & 5 hours & 25 hours & 40 hours & $\begin{array}{l}2144 \\
\text { hours }\end{array}$ \\
\hline $\begin{array}{l}4^{\text {th }} \text { Quarter } \\
\text { (October- } \\
\text { December) }\end{array}$ & 15 hours & 10 hours & 20 hours & $\begin{array}{l}1351 \\
\text { hours }\end{array}$ \\
\hline $\begin{array}{l}\text { Unit Profits } \\
\text { Francs }\end{array}$ & 10800 & 19.975 & $\begin{array}{l}7.500 \\
\text { Francs }\end{array}$ & \\
\hline
\end{tabular}

\subsubsection{Specific Objectives}

1. Research and highlight the key environmental and socio-economic parameters (variables and constraints) related to the system under study.

2. Set up the related models at different periods in the light of the above defined parameters.

3. Apply to the selected model the optimization algorithms and the necessary software tools in order to bring about an optimal solution. 4. Conclusion.

\subsection{Scenario of the study}

- Hypotheses :

1. We take into account three periods of 15 years of drying up of Lake Chad Basin, namely the years 1960 to 1975,1975 to 1990 and 1990 to 2005 . Each of the periods is a phase of shrinkage of the lake. These strictures are accompanied by significant sand deposits which settle out over time.

2. Changes in structures of the basin affect the production activities of the three categories of local people selected as subjects for our project: fishermen, farmers and breeders. These three categories of people are naturally attached in their entirety to their production or subsistence activities and from which they derive the bulk of their income.

3. The consistency of income of the three categories of the target populations also depends on the costs related to the fertility of their area of activity: fishing area for fishermen, that of arable land to farmers and finally the pasture and water bodies for breeders.

\subsection{Table of simulation data}

Experimental statements made on the field by considering the abovementioned assumptions helped us through the operations research tools to determine the different variables related to our field of study. The following tables give us the summary of the various statements for the three periods of lake water shrinking (1960-1975, 1975-1990 and 1990-2005). In the three tables the following are reported:

- In the column: length per ton of product.

- In lines: the quarterly average of the 15 years of the period.

- In the last column: the temporal availability.

- In the last line: unit profits by product type.

\subsection{Sources: Our elaboration, 2013}

In our previous article[1] we treated the primal problem in its canonical form by the method of simplex tables.

- In our current approach we get:

Table 2: Production in the four quarters of production operations 1990-2005

\begin{tabular}{|c|c|c|c|c|}
\hline $\begin{array}{l}\text { Duration in } \\
\text { hour per } \\
\text { tons of the } \\
\text { products } \\
\text { Quarteriy } \\
\text { Subdivisions } \\
\qquad\end{array}$ & $\begin{array}{l}\text { Number of } \\
\text { hours per } \\
\text { ton of fish }\end{array}$ & $\begin{array}{l}\text { Number of } \\
\text { hours per } \\
\text { ton of } \\
\text { agricultural } \\
\text { Products }\end{array}$ & $\begin{array}{l}\text { Number } \\
\text { of hours } \\
\text { per ton of } \\
\text { Breeding } \\
\text { Products }\end{array}$ & $\begin{array}{l}\text { Available } \\
\text { Hour } \\
\text { Volumes }\end{array}$ \\
\hline $\begin{array}{l}1^{e r} \text { Quarter } \\
\text { (January- } \\
\text { March) }\end{array}$ & 40 hours & 80 hours & 120 hours & $\begin{array}{l}7740 \\
\text { hours }\end{array}$ \\
\hline $\begin{array}{l}2^{\text {nd }} \text { Quarter } \\
\text { (April- } \\
\text { June) }\end{array}$ & 80 hours & 120 hours & 160 hours & $\begin{array}{l}7660 \\
\text { hours }\end{array}$ \\
\hline $\begin{array}{l}3^{\text {rd }} \text { Qarter } \\
\text { (July- } \\
\text { September) }\end{array}$ & 10 hours & 50 hours & 80 hours & $\begin{array}{l}4288 \\
\text { hours }\end{array}$ \\
\hline $\begin{array}{l}4^{\text {th }} \text { Quarter } \\
\text { (October- } \\
\text { December) }\end{array}$ & 30 hours & 20 hours & 40 hours & $\begin{array}{l}2702 \\
\text { hours }\end{array}$ \\
\hline $\begin{array}{l}\text { Unit Profits } \\
\text { Francs }\end{array}$ & $\begin{array}{l}54000 \\
\text { Francs }\end{array}$ & $\begin{array}{l}9988 \\
\text { Francs }\end{array}$ & $\begin{array}{l}3750 \\
\text { Francs }\end{array}$ & \\
\hline
\end{tabular}

$\min W=7.740 y_{1} "+7.660 y_{2}+4.280 y_{3} "+2.702 y_{4}$

With the constraints of non-negativity or positivity:

$y_{1} " \geq 0, y_{2} " \geq 0, y_{3} " \geq 0, y_{4} " \geq 0$

Subject to the constraints (S / C)

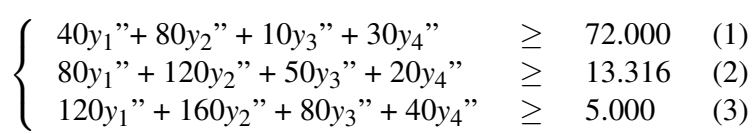

\subsection{Solving equations}

To solve these three inequations systems using the "dual simplex" method, we used the simplex algorithm designed by Matlab. This algorithm allowed us to determine the main variables of the three systems of inequations and the three economic functions related to it, namely $W_{1} ; W_{2}$ and $W_{3}$.

These values are:

1) For the period 1960 to 1975

$y_{1}=-5465608.49$
$y_{3}=1070816184$

and $W_{1}=-1.98595 E+12 F$

2) 1975-2000:

$y_{1}^{\prime}=-143331859$
$y_{3}^{\prime}=482224647$

and $W_{2}=-9.9607 E+11 F$

$y_{2}^{\prime}=-192143144.8$
$; y_{4}^{\prime}=440254799$

3) $1975-2000$

$y^{\prime \prime}=-1506040006 ;$

$y_{3} "=1129528028 ;$

and $W_{3}=-3.21728 E+12 F$ $y_{2} "=470638266.5$;

$y_{4} "=376511022$ $y_{2}=-691659601.5 ;$

$y_{4}=1494781581$; 


\section{Conclusion}

Even when the "dual simplex" method is applied as is the case in the present work, the results clearly confirm the negative effects of the drainage phenomenon of Lake Chad Basin on production costs of the three target local residents as already demonstrated in our previous article.

These costs increased remarkably by going from the average spending cost $W_{1}=-1,98595 E+12 F$ of the base period 1960-1975 then to the level $W_{2}=-9,9607 E+11 F$ obtained during the period 19751990 , and to finally reach its highest level $W_{3}=-3,21728 E+12 F$ in 1990-2005.

Moreover, this increasing trend of production costs for the target riparian populations is explained by the decrease in the quantity of a same type of foodstuff produced from one period to another. Indeed,

$$
\left\{\begin{array}{l}
1) y_{1}<y_{1}^{\prime}<y_{1}{ }^{\prime}, \\
\text { 2) } y_{2}<y_{2}^{\prime}<y_{2}{ }^{\prime} \\
3) y_{3}<y_{3}^{\prime}<y_{3} " \\
4) y_{4}<y_{4}^{\prime}<y_{4}{ }^{\prime}
\end{array}\right.
$$

- Further research:

It becomes imperative for researchers to develop this study in various directions. For example, we can next time tackle the situation of other neighboring Lac Chad Basin riparian populations such as: 1) producers of natron (natural sodium bicarbonate) and Spirulina in its natural state; 2 ) seasonal workers (fishing laborers, farm laborers and guards / livestock herdsmen; 3 ) the fauna and flora / biodiversity; 4) migration phenomena due to the loss of jobs linked to the drying up of Lake Chad-basin. Finally, the way is now open to any researcher or team of researchers available and ready to try out their work or compete with others in order to bring their contribute to solving a problem with global consequences.

\section{References}

[1] Marayi Choroma, Bakari ABBO, Bassono Francis, Abba DANNA Pare YOUSSOUF, Adv.Difference. Equ. Processe Control. Volume 12, Number 1, 2013, Pages 51-62.

[2] BRUNO SIMEONE: Metodi Matematici di Ottimizzazione, Dipartimento di Statistica, Probabilità e statistiche Applicate, A.A. 1994-1995, Università la "SPIENZA" di Roma (Italia), pp.194.

[3] André GROSDIDIER: Outils Mathématiques de Gestion, Editions Foucher, 1996, Paris (France), pp. 478.

[4] Rejeb HAJI: Recherche Opérationnelle, Collection FARH, 2003, Tunis, (Tunisie, pp.291.

[5] Robert Faure, bernard Lemaire, Christophe Picouleau: Précis de Recherche Opérationnelle, Editions DUNOD, 2009, Paris, (france), pp.571.

[6] BRUNO SIMEONE: PREFERENZE E DECISIONI, Scuola di Specializzazione in Ricerca Operativa e Strategie decisionali,università di Roma "La Sapienza", 1998-1999, Roma (Italia), pp.215.

[7] Mohamed AIDAINE et Brahim OUKACHA: Recherche Opérationnelle - Programmation Linéaire, Editions Pages Bleues internationales Maison d'Editions pour l'enseignement et la formation, 2005, Bouira 5ALGERIE), pp.204.

[8] Boualem BENMAZOUZ: Recherche opérationnelle de gestion, Atlas Editions, 1995, Alger (ALGERIE), pp.247.

[9] Daniel de WOLF: Gestionde la Production, Université de Liège, licence en Sciences de Gestion et Ingénieurs de Gestion, 2005, Liège (BELGIQUE), pp.242.

[10] Janet Roitman : Autour du lac Tchad : intégrations et désintégrations Juin 2004.

[11] Van Cotthem, W (2009): l'assèchement du lac Tchad menace les moyens d'existence des riverains, online unter http://nethumanitaires.wordpress.com/2009/10/15/lassechement-du-lac-tchadmenaceles-moyens-dexistence-des-riverains-fao/ Zugriff 25. 11. 2009. 